\title{
Nutritional Requirement of Olive (Olea europaea L.) in Pothwar Region of Pakistan: A Review
}

\author{
Muhammad Jan ${ }^{1 *}$, Muhammad Ashraf Sumrah ${ }^{1}$, Shoaib Akhtar ${ }^{1}$, Inam U1 Haq ${ }^{2}$, Muhammad Ramzan \\ Anser $^{1}$ and Iqra Yasmin ${ }^{1}$
}

${ }^{1}$ Centre of Excellence for Olive Research and Training (EFFORT), Barani Agricultural Research Institute (BARI), Chakwal, Pakistan; ${ }^{2}$ Barani Agricultural Research Institute, Chakwal, Pakistan.

Abstract | Olive (Olea europaea L.) fertilization considered as one of the important factor for production
of olive fruit and oil. Keeping in view the modern fruit production physiology, nutrients serve as stimulants
for cell development and fruit production. In Pakistan, Olive cultivation and production started from a
previous one decade. Farmers have a lack of trend for fertilizer application to Olive orchards in a proper dose.
Olive intensification for new orchard enhanced fertilizer use especially Nitrogen (N), Phosphorus (P) and
Potassium (K) and in micronutrients especially Boron (B) to control alternate bearing of olive. In Pakistan,
olive plantation is an initiative to minimize the Olive import, and to maximize olive plantation in Pothwar
area as well as control climate change. There is no trend for fertilizer application among the Pakistani farmers.
The increasing demand of olive oil and value added products like pickles jams and squash enforcing the
farmer to produce more and more. The increasing demand creates the competition among the farmers. To
produce more it is important to apply fertilizer at a right time, right source and right method. In case of soil
application, apply first dose of nitrogen, all phosphorus and all potassium fertilizers during the December.
Apply second dose during May-June and third dose during September in Pothwar. Foliar application is
suitable during end February and March. Drip irrigation is suitable during December and May.
Received | March 11, 2021; Accepted | May 15, 2021; Published | September 14, 2021
*Correspondence | Muhammad Jan, Centre of Excellence for Olive Research and Training (EFFORT), Barani Agricultural Research Institute
(BARI), Chakwal, Pakistan; Email: mjanleghari@gmail.com
Citation | Jan, M., M.A. Sumrah, S. Akhtar, I.U. Haq, M.R. Anser and I. Yasmin. 2021. Nutritional requirement of olive (Olea europaea L.) in
Pothwar Region of Pakistan: A review. Sarbad Journal of Agriculture, 37(4): 1334-1341.
DOI | https://dx.doi.org/10.17582/journal.sja/2021/37.4.1334.1341
Keywords | Fertilization, Fruit production, Nitrogen, Olea europaea, Oil quality

\section{Introduction}

$\mathrm{O}$ live (Olea europaea L.) reputed as most prominent fruit tree in worldwide as of its economic importance regarding valuable fruit and oil (Arquero et al., 2006; Erel et al., 2016; Fernandez-Escobar and Mundi-prensa, 2010). In the world, Olives (Olea europaea L.) cultivated an area of 10513320 hectares and having a production of 21066062 tonnes (Centeno et al., 2020). Production share of olive in world is i-e. Europe has covered the $63 \%$ olives of world, after
Europe, Africa has 19.7\%contribution and Asia is $13.4 \%$ olive production share (Erel et al., 2017). Turkey, Italy, Spain, and Greece are the considered as main oil producing countries (Haberman et al., 2019). Olive can play its essential role in our country's economy. Pakistan's aggregate household edible oil use is around 2.9 million tons. Approximately, 67\% of this consumption met by imports. Annually 38 billion rupees were for this purpose. Thus, giving careful consideration to increase the olive cultivation in Pakistan can help saving foreign reserve. In 
Pakistan, domesticated olive grown commercially on large scale. About 45 million olive trees are present in these areas, which showed the huge potential of this crop in Pakistan (Azmat et al., 2020).

Pakistan Agriculture Research Center (PARC) introduce olive in Pakistan under an Italian project "Fruit, Vegetable and olive Project" which was conducted to identify wild olive through a survey. Eighty million wild olive plants observed in different district of Pakistan. Currently, Barani Agricultural Research Institute (BARI), Pakistan registered eleven olive varieties. In BARI, according to Olive valley and Pakistan Seed Development Program (PSDP) projects olive plantation in Punjab Pakistan was 1,77,4019 and 75,250 respectively (Table 1). Total plantation in Pakistan is now 4039768 by PARC and BARI source (Khaliq et al., 2020). The area under olive cultivation in Punjab provinces is 13,324 acre and number of plants are 1798741. Olive is being cultivated in Pothwar region of Punjab provinces of Pakistan but Chakwal district's contribution is highest. Chakwal 3285.00 acres area is under olives cultivation. Overall in Pothwar, Olive is cultivated an area of 8615 acres (Figures 1 and 2).Pakistan have a bright future for Olive production especially in the belt of Koh-e-Suleman area. BARI Chakwal initiated Olive adaptability trials under Center of Excellence for Olive Research and Training (CEFORT) Project in the Southern Punjab Districts after its successive in Pothwar area. After a decade, those planted trials will be a great contribution for oil production (Source: BARI, Chakwal). The area under olive crop may increase in future due to crop diversification and rapid recovery of investment (https://www.technologytimes.pk/2020/10/12/olivecultivation-to-boost-green-economy-of-pakistan/; Masood et al., 2021).

The increasing demand of Olive oil and its value added products like Olive pickles, jam, squash, muraba, candies and other sweet products enforcing farmers to produce more and more fruit. To fulfill this demand, it is important to produce through a balance fertilizer application. Best management practices can play an important role in improving quality and yield of olive. Balanced use of nutrients can enhance the flowering, fruit size, fruit set and fruit's biochemical quality (Zipori et al., 2020). Olive growers cannot ignore the effects of macro and micronutrients on plant's health. They must give due importance to balanced use of nutrients (Zaragoza et al., 2020). Nutrients, which are essential for growth, are required at different physiological stages. Macronutrients are required in larger amount as compared to micronutrients but both of these are essential for plant growth, good quality fruit and higher yield. With balanced use of fertilizer, farmers can get better crop with more yields (Jimenez-Moreno and Fernandez-Escobar, 2017; Haberman et al., 2019).

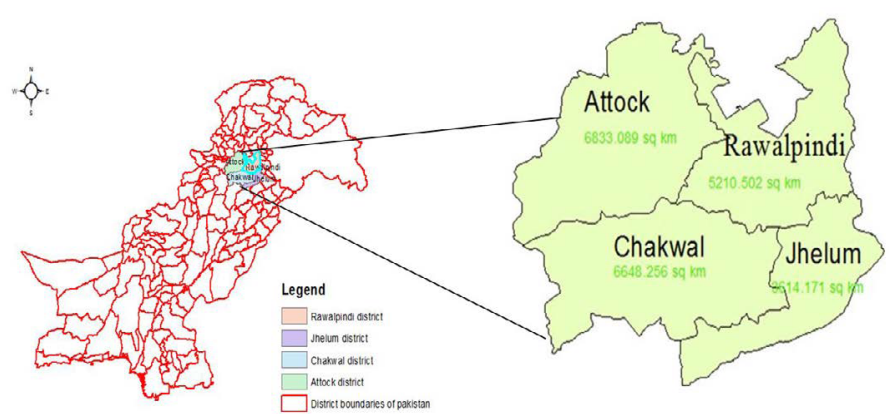

Figure 1: Map of pothohar region of Pakistan.

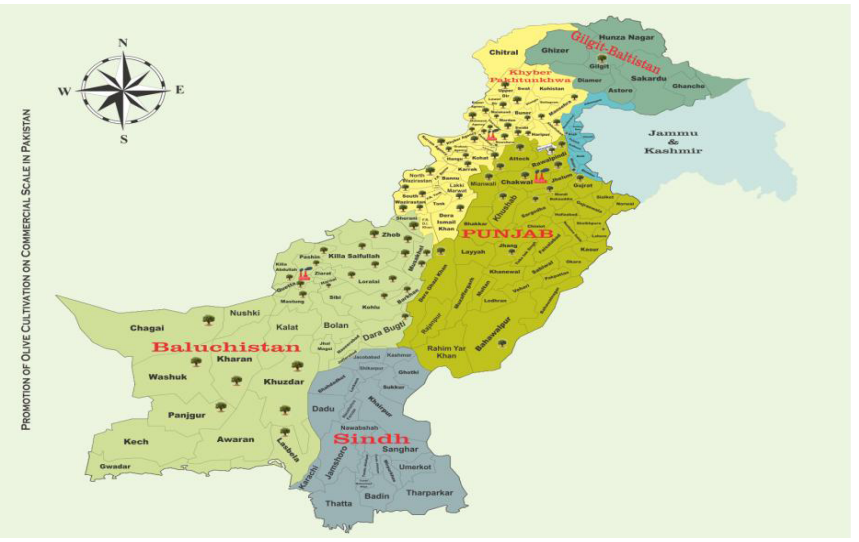

Figure 2: Existing Olive Plantation in Pakistan (2012-19).

Table 1: Projects wise detail for olive plantation in Pakistan (2012-2020).

\begin{tabular}{|c|c|c|c|c|c|c|}
\hline Provinces/Region & $\begin{array}{l}\text { PISDA (2012- } \\
\text { 14) }\end{array}$ & PSDP (2014-20) & $\begin{array}{l}\text { Olive Valley (2015- } \\
\text { 20) }\end{array}$ & $\begin{array}{l}5 \text { million olive (2013- } \\
\text { 19) }\end{array}$ & $\begin{array}{l}\text { Private planta- } \\
\text { tion }\end{array}$ & Total \\
\hline Punjab & 116,772 & 461,558 & 1250616 & & 10,000 & $1,798,741$ \\
\hline Khyber Pakhtunkhwa & 265,273 & 352,580 & - & 590,000 & 25,000 & $1.229,653$ \\
\hline Balochistan & 159,379 & 744,462 & - & - & 2,500 & 898,341 \\
\hline AJK & 421 & 13,360 & - & - & - & 13,781 \\
\hline ICT & 35,768 & 44,079 & - & - & - & 76,280 \\
\hline Gilgit & 2545 & 5660 & - & - & - & 8,205 \\
\hline Total & 580158 & 1621699 & $1,21,411$ & 590,000 & 37,500 & $4,039,768$ \\
\hline
\end{tabular}

Source: BARI Chakwal. 
Currently, olive growers focused on increasing productivity by increasing tree density, improving oil yield and enhancing the olive oil quality. Both irrigation and fertilization are two common horticultural practices that growers use to achieve these purposes and should be adapted to the orchard density and cultivar requirements. In most of the olive growing areas in Spain, fertilization carried out annually by applying the same fertilization program every year, without prior knowledge of the annual needs of the crop. However, many works confirm that when olive leaves are at adequate level of nutrients, N,P or K fertilization does not always produce increases in productivity, growth or oil quality (Valamoti et al., 2018; JimenezMoreno and Fernandez-Escobar, 2017). However, these studies focused Olive importance and fertilizer application in the Mediterranean climate but none of them reviewed about nutritional requirement of Olive in Pothwar climate. This study therefore planned to study the nutritional requirement of Olive in Pothwar region of Pakistan.

\section{Materials and Methods}

The review based on the given literature, which described Olive cultivation and its fertilizer management in Pothwar climate of Punjab, Pakistan. Another source of information was the internet source and online open access journals like Research ate, Scopus, Academia edu, Elsevier and other associations. The Literature included through judgement of related research articles, considering the climate of region and English language articles. Finally, to ensure related research articles, 50 used for the review.

\section{Results and Discussion}

\section{Olive cultivation in Pakistan}

There is sufficient potential for Olea europaea cultivation in Pakistan. Pothwar area is an arid region of Pakistan, which is enriched with natural vegetation (Azmat et al., 2020; Khaliq et al., 2020). Pothwar region (Salt range) is a sub mountainous area with arid subtropical climate. Its annual average temperature is $22.3^{\circ} \mathrm{C}$ while annual average rainfall is $519 \mathrm{~mm}$ (Masood et al., 2021). A minimum and maximum temperature of $2^{\circ} \mathrm{C}$ and $43^{\circ} \mathrm{C}$ recorded in the winters and summer respectively in Pothwar area. The olive cultivars growing in Pothwar region vary both physiologically, morphologically and variation exists among tree, endocarp, fruit, leaf, oil content, oil attributes, self-fertilizing ability, yield, vulnerability to specific diseases and so forth. Currently, in Pakistan Olive is cultivating in the areas of Chakwal, Jhelum, Attock, Khushab, Mianwali, Rawalpindi, Zhob, Musakhail and Azad Kashmir (Azmat et al., 2020).

\section{Importance of olive oil}

The production of olive oil considered as an important asset not only in term of health and culture as well as wealth of the farmer from a marginal land. In the previous few decades as olive production increased as it is a source of essential fatty acids and antioxidants in diet of human being (Cicerale et al., 2012; Preedy and Watson, 2020). The presence of functional bioactive compounds, fatty acids and antioxidants gave an importance to olive oil hence it considered as a famous diet of Mediterranean areas people (Souilem et al., 2017; Zouari et al., 2020).

\section{Importance of olive fruit}

Olive cultivars have a variety of variation regarding fruit size shape, size and composition. Olive fruit have composition of water (50\%), oil (22\%) and remaining $28 \%$ consist of pectin, cellulose and hemicellulose (6\%), protein (1.62\%) and $1.5 \%$ minerals, lignin, and volatile compounds (Khaliq et al., 2020). It also contained bioactive compounds like $\beta$-sitosterol, squalene, pigments, $\alpha$-tocopherol and a portion of hydrophilic bioactive compounds (Cicerale et al., 2012). In olive fruit, oil and water are two main phases, which distributed in skin, pulp and seed. Maximum oil accumulated in the pulp of fruit. Bioactive compounds distributed between water and oil phases during processing process depending upon mass transfer behavior and their solubility. The contents of tocopherols and sterols are 224 fold more in seed as compared to pulp while squalene detected only in pulp oil (Khanum et al., 2020).

\section{Nutritional status of Pakistani soils}

Pakistani soils are alkaline and deficient in micronutrients. Olive cultivation in hilly areas facing the nutrient deficiency of $\mathrm{P}$ and $\mathrm{K}$ both. Competition to produce more among the farmers is need to keep a proper dose of nutrients for good fruit yield and best oil quality. A diagnostic field survey of Pothwar region demonstrated that only 30\% farmers are aware with fertilizer application in olive orchard and remaining $70 \%$ never use any fertilizer. There are different factors that are responsible for low yield in Pothwar region 
like alkaline $\mathrm{pH}$, low organic matter, sandy and stony soils, $\mathrm{P}$ and $\mathrm{K}$ deficiency. In developing countries, more attention being paid towards the deficiency of micronutrients (Zia et al., 2006; Khattak and Hussain, 2007; Jamal and Jamal, 2018).

\section{Nutritional requirement of olive}

Fruit trees differs among the other annual plants because of lower nutrient requirements, having the storage organs to reuse and to support new growth including the olive. In case of fruit trees, actually a nutrient applied to promote plant growth and yield as well as its economic response is expected. It is a perception among the farmers that application of more fertilizer increase yield in the same rate while excess dose ultimately leads to environmental hazards and having adverse effect for both the tree and crop (Zaragoza et al., 2020). The objective of the current review was to discuss the nutritional requirement of olive for the sustainable management of olive orchards in pothwar region of Pakistan.

\section{Nitrogen (N)}

Nitrogen is one of the most important nutrient, which need in large quantity as compare to the other nutrients. Nitrate $\left(\mathrm{NO}_{3}{ }^{-}\right)$form of $\mathrm{N}$ is preferable as compare to ammonical form $\left(\mathrm{NH}_{4}^{+}\right)$. It is important to apply $\mathrm{N}$ in three split doses. Its application after pruning and before flowering can produce a profitable yield. Nitrogen application in optimum dose results into more shoot growth having a potential of yield in the coming season (Haberman et al., 2019). Nitrogen can be apply in soil, foliar, and fertigation. Soil and foliar $\mathrm{N}$ application is common in extensive, nonirrigated olive orchards and these both methods are helpful to minimize soil $\mathrm{N}$ dynamics in soil (Fernández-Escobar et al., 2009) while fertigation is common in irrigated orchards. Fertigation is the common practice, allowing maintenance of high levels of available soil $\mathrm{N}$. Excessive dose of $\mathrm{N}$ in both cases will lead to disturbance of flower initiation and fruit set which ultimately lead to lower fruit production (Chatzissavvidis and Therios, 2010). Furthermore, higher dose of $\mathrm{N}$ will result into poor oil quality, especially through reduction in polyphenol levels and free fatty acid content of oil. For Pothwar region its better apply $\mathrm{N}$ into three split doses. Apply first doses with farmyard manure (FYM) during December in case of soil application, foliar application during end Feb and March.
Nitrogen application during dormancy will lower nitrogen use efficiency. Nitrogen use efficiency is also dependent on nitrogen status of plant. Nitrogen deficient plant take up $\mathrm{N}$ rapidly as compared to $\mathrm{N}$ sufficient plant (Fernández-Escobar et al., 2009). Annual application of $\mathrm{N}$ to a sufficient $\mathrm{N}$ plant will reduce NUE and results into over fertilization. $\mathrm{N}$ is a basic macronutrient that is require in large quantity. Its application is mostly common in olive orchards. Deficiency symptoms of $\mathrm{N}$ become obvious in the older leaves and characterized by yellowish-green leaves (Fernández-Escobar et al., 2008; Hawkesford et al., 2012; Erel et al., 2017).

Alternate bearing is mostly common in olive plant, which influence $\mathrm{N}$ dynamic. New leaves store $\mathrm{N}$ during the off-season that mobilized in the leaves during on season that support the new growth (Erel et al.,2013; Zaragoza et al., 2020). Olive fruit considered as one of the major $\mathrm{N}$ sink, which is dependent on the adjacent leaf, and are helpful for olive fertilization. Nitrogen application during $\mathrm{ON}$ season through foliar application mobilized to the fruit. This rapid translocation give a way for explanation of excess $\mathrm{N}$ determination, which results into over fertilization (Haberman et al., 2019; Zipori et al., 2020).

\section{Phosphorus (P)}

Pakistani soils are phosphorus deficient because of alkaline $\mathrm{pH}$, low organic matter content, no trend of fertilizer application among fertilizers. Phosphorus mobility is very low and the plant mostly up takes it by root interception. It is mostly uptake by the plant in the anionic $\left(\mathrm{HPO}_{4}^{-}\right.$or $\mathrm{H}_{2} \mathrm{PO}_{4}^{-}$) form (Khattak and Hussain, 2007). Phosphorus have a direct impact on reproductive cycle that ultimately contributes to yield. Apical chlorosis turned leaf color from red and purple progressively which results into leaf collapse and leaves fall. Reproductive development of olive also affected due to $\mathrm{P}$ deficiency. Olive plants reused $\mathrm{P}$ and in fruit about $0.5 \mathrm{~g} \mathrm{Kg}^{-1} \mathrm{P}$ removed by olive fruits (Jimenez-Moreno et al., 2017; Erel et al., 2016; Souilem et al., 2017).

\section{Potassium (K)}

Potassium deficiency is mostly common in Pothwar areas because of calcareousness, and no canal water availability. Potassium actually increased the starch contents and considered one of the most important mineral due its higher concentration in fruit flesh (Restrepo-Diaz et al., 2008; Zipori et 
al., 2020). Potassium absorbed by the plant only in the cationic $\left(\mathrm{K}^{+}\right)$form but its availability increased through fertigation compared to broadcasting and foliar. Potassium have a role in stomatal regulation, stomatal regulation, carbohydrates assimilation and starch synthesis in olive (Morales-Sillero et al., 2007; Zaragoza et al., 2020).

It is important to apply potassium fertilizers because large concentration removed by the crop, and and it is involved more than $50 \%$ of fruit mineral composition. Deficiency of $\mathrm{K}$ frequently reported in olive orchards having calcareous soil under rain fed conditions (Restrepo-Diaz et al., 2008). Shoot defoliation, leaf tip necrosis and wrinkled fruit are the prominent $\mathrm{K}$ deficiency symptoms. These symptoms are mostly common in clayey soil because of potassium fixation in clayey soil. In such cases, $\mathrm{K}$ deficiency considered as a nutritional disorder in olive orchards (RestrepoDiaz et al., 2009; Zia et al., 2006).

Potassium deficiency symptoms cannot have corrected easily because of less absorption (Arquero et al., 2006). It is useful only in the condition if deficiency symptoms can have diagnosed by leaf analysis, Potassium have a low mobility in soil and it exist in the root system proximity. Foliar spray of 1-2\% recommended under rainfed conditions while fertigation is suitable under irrigated conditions (Restrepo-Diaz et al., 2009; Zia et al., 2006). In case of Pothwar, it is important to apply potassium fertilizer with FYM during December.

\section{Boron (B)}

Among the micronutrients, Boron (B) is one of the most nutrient for olive growth. Boron availability to plants decreased under low moisture content, high $\mathrm{pH}$ and calcareous soil. Boron leaf deficiency symptoms appears on the younger leaves having characteristics of apical chlorosis, witches and broom shoot growth and fruits having deformed shape (Stellacci et al., 2008). In case of severe B deficiency, fruit shape will be like Monkey mouth. Boron deficiency confused with $\mathrm{K}$ deficiency so it is important to analyze leaf samples and then apply specific nutrient otherwise B toxicity will be toxic for the plants (Vishekaii et al., 2019). In case of Olive it was observed that remobilization from phloem to flowers and fruit during flowering to supply B. Boron deficiency removed mostly through B foliar application in Olive orchards. This method is preferable in the conditions of calcareous soil and drylands, foliar spray of $0.1 \% \mathrm{~B}$ are preferable. In case of soil application, the application of 25-40 $\mathrm{g}$ boron tree $^{-1}$ for bearing orchard is suitable to control B deficiency (Haberman et al., 2019; Erel et al., 2017).

\section{Conclusions and Recommendations}

Nutritional requirement of olive is a basic consideration because an olive plant cannot complete its life cycle without applying adequate nutrition. In this review, it is concluded that nutrition is a prerequisite for olive vegetative, reproductive growth and development as well as for oil quality because to compete the current olive oil and its products it is needful to supply a proper dose of mentioned nutrients. On the other hand, fertilizer extensive use in an intensive olive orchard will follow the pollution risk as well as impair fruit production and oil quality. Sustainable management of fertilizer use will improve economic and control pollution in olive orchards. In Pakistan, olive plantation is an initiative to minimize the olive import, and to maximize olive plantation in Pothwar area as well as control climate change. There is no trend for fertilizer application among the Pakistani farmers. The increasing demand creates the competition among the farmers. Future research is need to asses to find the best fertilizer application stage for olive and to find out alternate bearing control through proper use of fertilizer.

\section{Acknowledgments}

We wish to Acknowledge Muhammad Rafiq (Project Director) and Muhammad Ashraf Sumrah (Deputy PD) of Centre of Excellence for Olive Research and Training (EFFORT), BARI Chakwal for the support and leadership

\section{Novelty Statement}

This study is a review of olive importance and fertilizer application in Pothwar area, which is an indication of fertilizer role for olive orchards. This study will be an addition of Olive cultivation in Pakistan and its nutrient management for Pothwar olive orchards to get more yield and a sustainable use of fertilizer in Pakistan.

\section{Author's Contribution}

MJ Conceived and designed the experiments: MAS Analyzed the data: IH Contributed materials/ 
analysis/tools: SA, MRA and IY Wrote the paper: All authors read and approved the final manuscript.

\section{Conflict of interest}

The authors have declared no conflict of interest.

\section{References}

Arquero, O., D. Barranco and M. Benlloch. 2006. Potassium starvation increases stomatal conductance in olive trees. Hortic. Sci., 41(2): 433-436. https://doi.org/10.21273/ HORTSCI.41.2.433

Azmat, M.A., I.A. Khan, A. Buerkert and M. Wiehle. 2020. Morphology, biochemistry, and management of Russian olive (Elaeagnus angustifolia L.) accessions in Gilgit-Baltistan, northern Pakistan. J. Agri. Rural Develop. Trop. Subtrop., 121: 151-160.

Boskou, D. 2006. Characteristics of the olive tree and olive fruit. Olive Oil. AOCS Press. pp. 1319. https://doi.org/10.1201/9781439832028. ch2

Boskou,D., G. Blekas and M.Tsimidou.2006. Olive oil composition. Olive Oil. AOCS press. pp. 4172. https://doi.org/10.4324/9781003040217

Bustan, A., A. Avni, U. Yermiyahu, A. Ben-Gal, J. Riov, R. Erel and A. Dag. 2013. Interactions between fruit load and macroelement concentrations in fertigated olive (Olea europaea L.) trees under arid saline conditions. Sci. Hortic. 152: 44-55. https://doi.org/10.1016/j. scienta.2013.01.013

Centeno, A., J.M. García and M. Gómez-delCampo. 2020. Vegetative, productive and oil quality responses of 'Arbequina' and 'Picual' olive trees to foliar $\mathrm{P}$ and $\mathrm{K}$ application. Grasa. Aceit., 71(2): 356. https://doi.org/10.3989/ gya.0102191

Chatzissavvidis, C. and I. Therios. 2010. Response of four olive (Olea europaea L.) cultivars to six B concentrations: Growth performance, nutrient status and gas exchange parameters. Sci. Hortic., 127(1): 29-38. https://doi. org/10.1016/j.scienta.2010.09.008

Cicerale, S.R.S.J., L.J. Lucas and R.S.J. Keast. 2012. Antimicrobial, antioxidant and antiinflammatory phenolic activities in extra virgin olive oil. Curr. Opin. Biotechnol., 23(2): 129-135. https://doi.org/10.1016/j. copbio.2011.09.006
Conde, C., S. Delrot and H. Gerós. 2008. Physiological, biochemical and molecular changes occurring during olive development and ripening. J. Plant Physiol., 165(15): 1545-1562. https://doi.org/10.1016/j.jplph.2008.04.018

Erel, R., Y. Yermiyhu, A. Ben-Gal and A. Dag. 2017. Olive fertilization under intensive cultivation management. VIII Int. Symp. Min. Nutr. Fruit Crops, 1217: 207-224. https://doi. org/10.17660/ActaHortic.2018.1217.27

Erel, R., Z. Kerem, A. Ben-Gal, A. Dag, A. Schwartz, I. Zipori and U. Yermiyahu. 2013. Olive (Olea europaea L.) tree nitrogen status is a key factor for olive oil quality. J. Agric. Food Chem., 61: 11261-11272. https://doi. org/10.1021/jf4031585

Erel, R., U. Yermiyahu, J. Van Opstal, A. Ben-Gal, A. Schwartz, and A. Dag, 2013. The importance of olive (Olea europaea L.) tree nutritional status on its productivity. Sci. Hortic., 159: 8-18. https://doi.org/10.1016/j.scienta.2013.04.036

Erel, R., U. Yermiyahu, J. Van Opstal, A. Ben-Gal, A. Schwartz, and A. Dag, 2016. Phosphorous nutritional level, carbohydrate reserves and flower quality in olives. PLoS One, 11: 0167591. https://doi.org/10.1371/journal.pone.0167591

Fernandez-Escobar, R. and J.D. Mundi-prensa. 2010. In Olive Growing, $1^{\text {st }}$ ed.; Barranco, D., Fernández-Escobar, R., Rallo, L., Eds.; Australian Olive Association Ltd.: Pendle Hill, Australia.

Fernández-Escobar, R., L. Marin, M.A. SánchezZamora, J.M. García-Novelo, C. Molina-Soria and M.A. Parra. 2009. Long-term effects of $\mathrm{N}$ fertilization on cropping and growth of olive trees and on $\mathrm{N}$ accumulation in soil profile. European J. Agron., 31(4): 223-232. https://doi.org/10.1016/j.eja.2009.08.001

Fernández-Escobar, R., M.A. Sánchez-Zamora, J.M. García-Novelo and C. Molina-Soria. 2015. Nutrient removal from olive trees by fruit yield and pruning. Hortic. Sci., 50(3): 474-478. https://doi.org/10.21273/HORTSCI.50.3.474

Fernandez-Escobar, R., R. Moreno and M.A. Sanchez-Zamora. 2004. Nitrogen dynamics in the olive bearing shoot. Hortic. Sci., 19: 1406-1411. https://doi.org/10.21273/ HORTSCI.39.6.1406

Fernández-Escobar, R., A. Ortiz-Urquiza, M. Prado and H.F. Rapoport. 2008. Nitrogen status influence on olive tree flower quality 
and ovule longevity. Environ. Exp. Bot., 64: 113-119. https://doi.org/10.1016/j. envexpbot.2008.04.007

García-Villalba, R., J.A. Giménez-Bastida, M.T. García-Conesa, F.A. Tomás-Barberán, J. Carlos Espin and M.Larrosa.2012.Alternative method for gas chromatography-mass spectrometry analysis of short-chain fatty acids in faecal samples. J. Separation Sci., 35(15): 1906-1913. https://doi.org/10.1002/jssc.201101121

Haberman, A., A. Dag, N. Shtern, I. Zipori, R. Erel, A. Ben-Gal and U. Yermiyahu. 2019. Significance of proper nitrogen fertilization for olive productivity in intensive cultivation. Sci. Hortic., 246: 710-717. https://doi. org/10.1016/j.scienta.2018.11.055

Hawkesford, M., W. Horst, T. Kichey, H. Lambers, J. Schjoerring, I.S. Møller and P. White. 2012. Functions of macronutrients. In Marschner's Mineral Nutrition of Higher Plants, $3^{\text {rd }}$ ed.; Marschner, P., Ed., Elsevier: Amsterdam, The Netherlands, pp. 135-189. https://doi. org/10.1016/B978-0-12-384905-2.00006-6

Jamal, A. and H. Jamal. 2018. Assessment and Distribution of Macro and Micro Nutrients in Different Soil Series of District Swabi, Khyber Pakhtunkhwa, Pak. J. Hortic. Plant Res., pp. 23. https://doi.org/10.18052/www.scipress.com/ JHPR.2.23

Jemai,H., M. Bouaziz and S. Sayadi. 2009. Phenolic composition, sugar contents and antioxidant activity of Tunisian sweet olive cultivar with regard to fruit ripening. J. Agric. Food Chem., 57(7): 2961-2968. https://doi.org/10.1021/ jf8034176

Jiménez-Moreno, M.J. and R. Fernández-Escobar, R. 2017. Influence of nutritional status of phosphorus on flowering in the olive (Olea europaea L.). Sci. Hortic., 223: 1-4. https://doi. org/10.1016/j.scienta.2017.05.028

Kaniewski, D., E. Van Campo, T. Boiy, J.F. Terral, B. Khadari and G. Besnard. 2012. Primary domestication and early uses of the emblematic olive tree: Palaeobotanical, historical and molecular evidence from the Middle East. Biol. Rev., 87(4): 885-899. https://doi.org/10.1111/ j.1469-185X.2012.00229.x

Khaliq, A., S.M. Ali Shah, M. Akram, M., N. Munir, M. Daniyal, M. Irshad and S. Ahmad. 2020. Determination of oil contents from eight varieties of Olea Europaea (Olive) grown in
Pakistan. Natl. Prod. Res., 34(13): 1951-1955. https://doi.org/10.1080/14786419.2019.1566 725

Khanum, F., T. Zahoor, M.I. Khan and M. Asghar. 2020. Biochemical profile of olive leaves grown in Olive Valley, Pakistan. Bio. Sci. PJSIR, 63: 9-16.

Khattak, R.A. and Z. Hussain. 2007. Evaluation of soil fertility status and nutrition of orchards. Soil Environ., 26(1): 22-32.

Masood, A., M. Manzoor, S. Anjum, A. Achakzai, S.H. Shah, S. Rizwan and A. Ullah. 2021. Quantitative analysis of total phenolics, flavonoids and antioxidant activity of olive fruits (Olea ferruginea) based on geographical region and harvesting time in Zhob district, Pakistan. Appl. Ecol. Environ. Res., 19(1): 13-25.

Mercuri, A.M., M.B. Mazzanti, A. Florenzano, M.C. Montecchi and E. Rattighieri. 2013. Olea, Juglans and Castanea: The OJC group as pollen evidence of the development of human-induced environments in the Italian peninsula. Quart. Int., 303: 24-42. https://doi. org/10.1016/j.quaint.2013.01.005

Morales-Sillero, A., R. Jiménez, J.E. Fernández, A. Troncoso and G. Beltrán. 2007. Influence of fertigation in 'Manzanilla de Sevilla'olive oil quality. Hortic. Sci., 42(5): 1157-1162. https:// doi.org/10.21273/HORTSCI.42.5.1157

Niaounakis, M., and C.P. Halvadakis. 2006. Olive processing waste management: Literature review and patent survey. Elsevier.

Papadaki,E.,M.Z.Tsimidou,andF.T.Mantzouridou. 2018. Changes in phenolic compounds and phytotoxicity of the Spanish-style green olive processing wastewaters by Aspergillus niger B60. J. Agric. Food Chem., 66(19): 4891-4901. https://doi.org/10.1021/acs.jafc.8b00918

Paraskeva, P. and E. Diamadopoulos. 2006. Technologies for olive mill wastewater (OMW) treatment: A review. J. Chem. Technol. Biotechnol. Int. Res. Proc. Environ. Clean Technol., 81(9): 1475-1485. https://doi. org/10.1002/jctb.1553

Preedy, V.R., and R.R. Watson. 2020. Olives and olive oil in health and disease prevention. Academic press.

Qureshi, M.S., R.W.K. Qadri, M.J. Jaskani and R. Ahmad. 2020. Morphological and biochemical assessment of eight olive genotypes growing in potohar region of Pakistan. Pak. J. Agric. 
Sci., 57(4): 1036-1043.

Restrepo-Diaz, H., M. Benlloch and R. FernándezEscobar. 2008. Plant water stress and $\mathrm{K}+$ starvation reduce absorption of foliar applied $\mathrm{K}^{+}$by olive leaves. Sci. Hortic., 116(4): 409-413. https://doi.org/10.1016/j.scienta.2008.03.004

Restrepo-Diaz, H., M. Benlloch and R. FernándezEscobar. 2009. Leaf potassium accumulation in olive plants related to nutritional $\mathrm{K}$ status, leaf age, and foliar application of potassium salts. J. Plant Nutr., 32(7): 1108-1121. https://doi. org/10.1080/01904160902943148

Souilem, S., A. El-Abbassi, H. Kiai, A. Hafidi, S. Sayadi and C.M. Galanakis. 2017. Olive oil production sector: environmental effects and sustainability challenges. In: Olive mill waste. Academic Press. pp. 1-28. https://doi. org/10.1016/B978-0-12-805314-0.00001-7

Stellacci, A.M., A. Caliandro, M.A. Mastro and D. Guarini. 2008. Effect of foliar boron application on olive (Olea europaea L.) fruit set and yield. VI Int. Symp. Min. Nutr. Fruit Crops, 868: 267-272. https://doi.org/10.17660/ ActaHortic.2010.868.35

Tekiki, A., R. Helal, M. Hassouna and S. Bornaz. 2018. Functional properties of a new spread based on olive oil and honeybees. Mediter. J. Chem., 6(6): 276-282. https://doi. org/10.13171/mjc66/01801182226-tekiki

Therios, I.N. 2009. Olives (Vol.18). CABI. https:// doi.org/10.1079/9781845934583.0000

Valamoti, S.M., E. Gkatzogia and M. Ntinou. 2018. Did Greek colonisation bring olive growing to the north? An integrated archaeobotanical investigation of the spread of Olea europaea in Greece from the $7^{\text {th }}$ to the $1^{\text {st }}$ millennium BC. Vegetat. Hist. Archaeobot., 27(1): 177195. https://doi.org/10.1007/s00334-0170631-1

Vierhuis, E., M. Servili, M. Baldioli, H.A.
Schols, A.G. Voragen, and G. Montedoro. 2001. Effect of enzyme treatment during mechanical extraction of olive oil on phenolic compounds and polysaccharides. J. Agric. Food Chem., 49(3): 1218-1223. https://doi. org/10.1021/jf000578s

Vishekaii, Z.R., A. Soleimani, E. Fallahi, M. Ghasemnezhad and A. Hasani. 2019. The impact of foliar application of boron nanochelated fertilizer and boric acid on fruit yield, oil content, and quality attributes in olive (Olea europaea L.). Sci. Hortic., 257: 108689. https:// doi.org/10.1016/j.scienta.2019.108689

Zaragoza,C.A., R.G.Perea,I.F. García,E.C.Poyato and J.A.R. Díaz. 2020. Open source application for optimum irrigation and fertilization using reclaimed water in olive orchards. Comp. Elect. Agric., 173: 105407. https://doi.org/10.1016/j. compag.2020.105407

Zia, M.H., R. Ahmad, I. Khaliq, A. Ahmad and M. Irshad. 2006. Micronutrients status and management in orchards soils: Applied aspects. Soil Environ., 25(1): 6-16.

Zipori, I., R. Erel, U. Yermiyahu, A. Ben-Gal and A. Dag. 2020. Sustainable management of olive orchard nutrition. Rev. Agric., 10(1): 11. https://doi.org/10.3390/agriculture10010011

Zohary, D., M. Hopf and E. Weiss. 2012. Domestication of Plants in the Old World: The origin and spread of domesticated plants in Southwest Asia, Europe, and the Mediterranean Basin. Oxford University Press on Demand. https://doi.org/10.1093/ acprof:osob1/9780199549061.001.0001

Zouari, I., B. Mechri, M. Tekaya, O. Dabbaghi, I. Cheraief, A. Mguidiche and M.A. Mezghani. 2020. Olive oil quality influenced by bio stimulant foliar fertilizers. Braz. J. Biol. Sci., 7(15): 3-18. https://doi.org/10.21472/ bjbs(2020)071501 